Розлуцька Г.М., Іваськевич В.3.

\title{
Вплив вестибулярного положення іклів на порушення комунікації в толерантному освітньому просторі
}

\author{
ДВНЗ «Ужгородський національний університет», м. Ужгород, Україна \\ grozlutska@ukr.net, vikiblonda@gmail.com
}

\author{
Розлуцкая Г. М., Иваськевич В.3. \\ Влияние вестибулярного положения клыков \\ на нарушение коммуникации в толерантном \\ образовательном пространстве \\ ГВУЗ «Ужгородский национальный университет», \\ г. Ужгород, Украина
}

Rozlutska G.M., Ivaskevych V.Z.

The Influence of vestibular position of canines on communication disturbance in tolerant educational space

"Uzhhorod National University", Uzhhorod, Ukraine

\section{Встуі}

Результат міжособистісної, групової, масової комунікації залежить від майстерності комунікантів у використанні словесного (вербального) інструментарію. Інформаційно-звукова система сигналів забезпечує усну комунікацію. Утворення звуків здійснюється за допомогою органів та рухів артикуляційного апарату людини. Поширені проблеми артикуляції пов'язані із зубощелепними аномаліями у $80 \%$ населення земної кулі, серед яких від $35 \%$ до $60 \%$ діти та молодь до 25 -ти років [1, c. 2]. У різні вікові періоди найбільш розповсюдженою зубо-щелепною аномалією є скупчення зубів, яка складає від $17 \%$ до 56\%. Серед аномалій розташування зубів превалює вестибулярне розташування ікол, яке сягає $62,8 \%$ [2, с. 42]. Відтак, актуалізуються міждисциплінарні дослідження проблеми комунікації детерміновані дефектами вимови, як наслідок зубощелепних аномалій, зокрема вестибулярного положення іклів.

Мета дослідження - виявити вплив зубо-щелепних аномалій на комунікацію в освітньому просторі.

Для досягнення поставленої мети необхідно виконати такі завдання:

- визначити особливості комунікації у просторі освіти;

окреслити вплив правильної вимови на толерантну взаємодію учасників освітнього середовища;

- розглянути роль зубних рядів як органів артикуляційного апарату у вимові звуків;

- на основі експертного опитування визначити вплив між артикуляцією звуків української мови та вестибулярним положенням іклів.

\section{Матеріали та методи}

В ході виконання дослідження було використано загальнонаукові та спеціальні методи. Для досягнення мети нами використано емпіричні, аналітико-синтетичні методи дослідження при аналізі джерел і науково-методичної літератури. Формуванню результатів дослідження сприяв системний підхід, структурно-функціональний аналіз, інтерпретація та узагальнення отриманих даних.

Необхідність міждисциплінарного підходу зумовило використання дослідницького інструментарію різних галузей науки, серед яких: мовознавство, психологія, соціологія, культурологія, логопедія, ортодонтія.

\section{Результати дослідження та їх обговорення}

Усне мовлення є складною інформаційно-звуковою системою виключно людської комунікації, яка відображає індивідуальні, національні, інтернаціональні чинники. Усне мовлення на практиці реалізується у відправлення мовленнєвого сигналу та його прийомі. Мовлення презентує здобутки особистості в культурологічній, соціальній, економічній, науково-технічній, політичній та інші сферах життя, тоді як дефекти у мовленні можуть викликати дискомфорт, стати причиною невдалого спілкування, непорозуміння, конфліктів та ін.

Оновлена у відповідності із нормами міжнародного права щодо захисту дитинства нормативно-правова база української освіти увиразнила зобов'язання освітнього закладу як гаранта здобуття освітніх послуг у толерантному освітньому середовищі [3]. Освітній заклад як суспільне та одночасно освітнє середовище зобов'язується забезпечити гармонійний розвиток особистості споживача освітніх послуг, його здоров'я, виховує ціннісне ставлення до самого себе, природного й соціального довкілля, виробляє механізми соціальної адаптації та творчої самореалізації у суспільстві.

Організаційно важливою характеристикою освітнього простору сучасного $є$ ефективна комунікація на засадах толерантності усіх учасників освітнього процесу. У наших дослідженнях освітній простір розглядається як 
комплекс умов, що забезпечують організацію комфортної життєдіяльності здобувача, що уможливлює його самореалізацію у національній та полікультурній сферах [4]. Дослідниця С. Смолюк вказує на інтеграцію в сучасному освітньому просторі низки соціо-культурних, психолого-педагогічних, здоров'язбережувальних та інших чинників (Смолюк, 2017, 138). На підставі праць О. Цимбалару (Цимбалару А, 2016, с. 44-45), зазначимо, що вагомим показником ефективності функціонування освітнього середовища та будь-якої його складової (здоров'язбережувальної, культурної, соціальної, інформаційної, тощо) $є$ взаємодія учасників освітнього процесу, яка під впливом зовнішніх або внутрішніх чинників може бути об'єктом цілеспрямованих змін. Отже, невід'ємною складовою освітнього простору є толерантне середовище для комунікації учасників освітнього процесу.

Комунікація в освітньому середовищі на засадах толерантності розглядається нами як форма соціальної комунікації, що у розрізі проблематики дослідження детермінується проблемами, що виникають при взаємодії у процесі спілкування як наслідок відхилень у вимові. При спілкуванні відбувається безпосередній контакт комунікантів через сприймання та обмін інформацією. Таким чином, можемо стверджувати, що толерантність як взаємодія вимагає порозуміння на кожному етапі: сприйняття, обробки інформації, прийняття рішення, дія. Пусковим механізмом є правильне сприйняття інформації реципієнтом, яке можливе при умові фонетичної чіткості в артикуліції комуніканта.

Артикуляцію трактують як роботу мовних органів, спрямовану на вимовляння того чи іншого звука мови або положення мовних органів при вимові звуків у процесі мовлення, і як передумову правильного звукотворення [7]. Важливо закцентувати увагу, що процес творення чітких звуків можливий лише за умови нормальної анатомофізіологічної будови та функціонування органів мовлення, зокрема артикуляційного апарату. Зуби вважають пасивним органом артикуляційного апарату, який забезпечує спеціальні перешкоди на шляху струменя повітря, що видихається [8]. Отже, будь-які дефекти зубних рядів можуть вплинути на відхилення у артикуляції звуків. У свою чергу, порушення звуковимови та неправильна артикуляція, інфантильний тип ковтання, порушення тонусу жувальних та мімічних м'язів спричиняють аномалії та деформації зубощелепної системи. Дослідження ортодонтів свідчать, що у дітей із аномаліями прикусу логопедичні порушення негативно впливають на ріст і формування зубощелепного апарату [9-11]. У праці К. М. Лихоти, О.В.Петриченко, Чжан Цянь вказано на Взаємовпливи зубощелепних аномалій i деформацій прикусу у дітей та функціональним станом зубощелепної системи. Серед факторів, що перешкоджають нормальній артикуляції у дітей зазначено звуження верхньої щелепи призводить до недостатнього тиску на зуби з боку губ, що в свою чергу, викликає розлади вимови [12].

Зауважимо, що кожній мові притаманна своя система артикуляції, свій спосіб членороздільного вимовляння звуків. Вимова голосних і приголосних звуків української мови має тенденцію до вертикальної артикуляції, яка утворюється шляхом округлення, передусім, голосних звуків. В українській мові найбільше передньоязикових приголосних. За положенням губ, вони всі так чи інакше наближені до «кола». 3 погляду фізіології артикуляції приголосні класифікують за місцем творення і способом творення. У ракурсі нашого дослідження $€$ особливості артикуляції губних (лабіальних) та передньоязикових міжзубних, зубних, піднебінних приголосних звуків. При творенні губних, губо-губних звуків до яких належать [б], [п], [м], губи змикаються i притискаються до зубних рядів. Артикуляція губнозубних або лабіодентальних приголосних [ф] і [в] вимагає змикання нижньої губи з верхніми зубами.

Наукове зацікавлення викликають особливості артикуляції кожного звука окремо, тому розглянемо їх детально. [б] - дзвінкий, [п] - глухий. Їх об'єднує те, що разом вони належать до групи губних зімкнених приголосних. Це означає, що в їх артикуляції головну роль відіграють губи. У цілому вона складається з двох етапів зімкнення i розімкнення губ. Після першого 3 них відбувається натиск повітря, після другого - він миттєво закінчується. Язик у цьому участі не бере, піднебіння підняте. У звучанні їх є певні відмінності. Так, [б] звучить більш напружено, дзвінко і твердо, а [п] - глухо, м'яко і невимушено. Слід зазначити, що напруженість і дзвінкість створюються голосовими зв'язками, а м'якість і невимушеність - губами і диханням. Губний зімкнений сонорний приголосний [м] артикулюється переважно губами. Натиску повітря і напруження голосу не потребує. Відрізняється від попередніх губних приголосних опущенням м'якого піднебіння, що відкриває тим самим прохід до носової порожнини та створює домішок носового звучання.

Так, як творення приголосного [п] потребує найбільшого натиску повітря, відповідно у його роль артикуляції значення зубощелепних аномалій, зокрема вестибулярного положення іклів $є$ значнішою у порівнянні iз звуками [б], [п]. Тоді як сонорні щілинні [в], [ф]. Артикулюються зближенням губів до утворення вузької щілини, через яку виходить струмінь повітря. Язик у цьому участі не бере, м'яке піднебіння підняте, прохід у носову порожнину закрито. Особливістю артикуляції [ф] $\epsilon$ зближення нижньої губи із зубами верхньої щелепи, при якому утворюється щілина трохи більша, аніж при вимові звука [в].

До передньоязикових відносять: [д], [3], [c], [д], [т], $[н],[д ж]$, [дз], [ц], [ч], [л], [р]. За пасивним артикулятором передньоязикові поділяють на міжзубні, або інтердентальні, зубні, або дентальні ([д], [т], [3], [с], [дз]), та піднебінні ([ж], [ш], [дж], [ч]. За акустикою вони бувають дзвінкими, глухими, свистячими, або шиплячими. Залежно від форми, якої набуває язик, та ділянки передньої частини язика, що бере участь у творенні звуків, розрізняють серед передньоязикових приголосних апікальні, дорсальні та какумінальні. При творенні апікальних кінчик язика (апекс) притискується до зубів, альвеол, ясен або загинається до твердого 
піднебіння. Апікальними є український зубний [л]. При вимові дорсальних спинка язика торкається піднебіння, а його кінчик опускається вниз, наближаючись до нижніх зубів. Дорсальними є українські [д], [т], [3], [с]. Какумінальні або церебральні, приголосні утворюються при піднятому вгору краї передньої частини спинки язика, наприклад звуки [ж], [ш], [р].

Артикулюються торканням кінчика язика внутрішньої сторони передніх верхніх зубів та альвеол дзвінкий [д], глухий [т]. Вони належать до групи зубних зімкнених приголосних. Артикулюються торканням кінчика язика внутрішньої сторони передніх верхніх зубів та альвеол. Губи пасивні, м'яке піднебіння опущене, прохід до носової порожнини відкрито. Різницю в звучанні цих приголосних створює вібрація голосових зв'язок при артикуляції [д]. Артикулюється [н], сонорний зубний зімкнений приголосний як і попередні [д], [т] торканням кінчика язика передніх зубів та альвеол. За рахунок більшої площини торкання язика та водночас відповідного опущення м'якого піднебіння він отримує специфічне носове звучання.

Вимовляють напіввідкритими при розімкнених на 1-2 мм зубах зубні приголосні звуки [c] - глухий щілинний, [3] - дзвінкий щілинний, [ц] - глухий зімкненощілинний. При цьому м'яке піднебіння підняте, отже, прохід до носової порожнини закрито. Язик виконує приблизно такий самий рух, як і під час артикуляції [д], [т], але не торкається піднебіння та утворює щілину між ним i передньою частиною спинки язика. Дзвінкий [ж], глухий [ш], сонорний [й] із щілинних передньопіднебінних приголосних артикулюються шляхом утворення щілини, як [3], [c]. Однак, кінчик язика не підіймається так високо, від чого канал, що утворюється спинкою язика, є значно ширшим. Струмінь повітря спрямовується на передні різці верхнього ряду. Зуби при цьому розімкнені на відстані 1-2 мм, м'яке піднебіння підняте. Різниця звучання створюється за рахунок роботи голосових зв'язок

Африкати [дз], [дж], що утворюються дзвінким зубним [3] та передньопіднебінними [д], [ж] приголосними належать до групи зімкнено-щілинних звуків. Артикуляція їх відображає не кожен складовий звук окремо, а їх злиття в один. Ця спільна риса має місце в артикуляції обох фонем, а ще спільним у них $є$ базова основа - твердий [д], який додає їм домішок початкового носового звучання. Різницю артикуляції [дз], [дж] складає другий елемент. Специфіка у артикуляції в тому, що при вимові другого елементу кінчик язика торкається передніх зубів нижнього ряду, але плавно переходить до верхніх альвеол, що й утворює щілинне звучання злитого [дж]. Тоді, як другий елемент артикуляції [дж] зумовлений специфікою другої частини цієї фонеми. Отже, зімкнення відбувається не на передніх зубах та альвеолах, а на твердому піднебінні, де утворюється звук [ж].

Глухий [ч] артикулюються шляхом торкання альвеол кінчиком язика, після чого в центральній його частині утворюється щілина. Губи відірвані від зубів, висунуті вперед, зуби розімкнені, м'яке піднебіння підняте, носова порожнина закрита. Струмінь повітря спрямовується на альвеоли, що знаходяться над передніми зубами верхнього ряду. Сукупність усіх цих елементів і створює специфіку звучання українських [ч], що відрізняється від артикуляції та вимови цих приголосних в інших мовах.

Передньопіднебінний сонорний щілинний приголосний [л], що вирізняється характерним розімкненням губ та змички кінчика язика з внутрішньою поверхнею передніх зубів верхньої щелепи. Струмінь повітря при цьому проходить крізь бокові щілини, які утворюються внаслідок опускання бокових країв язика. Напевно саме тому цей приголосний інколи називають ще боковим сонантом.

3 метою визначення впливу вестибулярного положення іклів на артикуляцією звуків української мови нами було проведено дослідження на базі оглядового стоматологічного кабінету поліклінічного відділення Ужгородської міської дитячої лікарні в рамках НДР кафедри стоматології дитячого віку стоматологічного факультету ДВНЗ «Ужгородський національний університет» на тему «Клініко-експериментальне обгрунтування застосування сучасних стоматологічних технологій та експертна оцінка якості лікування i профілактики основних стоматологічних захворювань у дітей i дорослих», державний реєстраційний номер 0109U00046. Група дослідження була сформована під час виконання профілактичних оглядів учнів освітніх закладів м. Ужгород. Для встановлення залежності між зубощелепними деформаціями, скупченим розташування зубів верхнього ряду і неправильною артикуляцією було проведено опитування компетентних експертів, залучених до огляду. В групу з 8-ми експертів було включено 1 психолога, 1 - логопеда, 2 - стоматологів; 2 - помічників лікаря, 2 - педагогічних працівників. Експертам було запропоновано вказати звуки на нечітку вимову, яких впливає вестибулярне положення ікл. Відповіді експертів наведені в таблиці.

Аналіз відповідей експертів було засвідчив, що більшість експертів відслідковують такі залежності: вестибулярне положення ікл супроводжується дефектами у вимові приголосних губних звуки ([б],[м],[п],[в],[ф]), чітка вимова яких залежить від якості змикання губ та передньоязикові міжзубні, зубні та піднебінні звуки: ([л], $[\mathrm{H}],[\breve{и ̆}],[ц],[ш],[ж], \quad[3],[\mathrm{c}],[ч], \quad[л], \quad[д],[\mathrm{T}]$, [дз],[дж], $[$ й],[ц],[ш],[ж], [3],[с], [ч], [л], артикуляція яких вимагає змикання язика, губ та зубів.

\section{Перспективи подальших досліджень}

Наше дослідження не вичерпує усіх аспектів окресленої проблеми. Перспективним напрямом подальшої роботи вважаємо розробку методичних рекомендацій для практичної діяльності логопедів та ортодонтів по усуненню дефектів мовлення. 
Таблиця. Залежність артикуляції від вестибулярного положення ікл

\begin{tabular}{|c|c|c|c|c|c|}
\hline \multirow[b]{2}{*}{$\begin{array}{c}\text { Номер } \\
\text { експерта }\end{array}$} & \multicolumn{5}{|c|}{ Особливості положення частин артикуляційного апарату при вимові звука } \\
\hline & зімкнення губ & $\begin{array}{c}\text { притискання } \\
\text { язика до } \\
\text { зубного ряду } \\
\text { верхньої } \\
\text { щелепи }\end{array}$ & $\begin{array}{c}\text { притискання язика } \\
\text { до зубного ряду } \\
\text { верхної щелепи і } 3 \\
\text { подальшим } \\
\text { зіскненням і } \\
\text { розімкненням губ }\end{array}$ & $\begin{array}{c}\text { регуляція струменю } \\
\text { повітря, що } \\
\text { видихається } \\
\text { передньою частиною } \\
\text { артикуляційного } \\
\text { апарату }\end{array}$ & $\begin{array}{c}\text { відсутність } \\
\text { перешкоди } \\
\text { струменю } \\
\text { повітря, що } \\
\text { видихається }\end{array}$ \\
\hline 1 & {$[б],[\mathrm{M}],[\Pi],[\mathrm{в}],[\phi]$} & [л], [н] & [ж],[дз],[дж] & [й],[ц],[ш],[ж] [3],[с] & [ч], [л] \\
\hline 2 & {$[б],[\mathrm{m}],[\Pi],[\mathrm{в}],[ф]$} & [л], [н] & [ж],[3], [дз],[дж] & 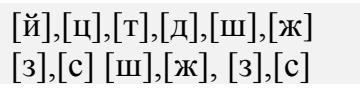 & [ч], [л] \\
\hline 3 & [б],[м],[в],[ф] & [л], [н] & [дз],[дж] & {$[и ̆],[ц],[ш],[ж][3],[c]$} & [ч] \\
\hline 4 & [б],[м],[п],[в], & [л] & [ж],[3], [дз],[дж] & {$[\breve{и}],[ц],[ш],[ж][3],[c]$} & [ч], [л] \\
\hline 5 & {$[б],[\mathrm{M}],[\Pi],[\mathrm{B}],[\phi]$} & [л], [н] & [дз] & {$[$ й],[ш],[ж], [3],[с] } & [ч], [л] \\
\hline 6 & {$[б],[\mathrm{M}],[\Pi],[\mathrm{B}],[\phi]$} & {$[\mathrm{H}]$} & [дз],[дж] & {$[\breve{u}],[ц],[ш],[ж][3],[c]$} & [ч], [л] \\
\hline 7 & {$[б],[\Pi],[в],[ф]$} & [л], [н] & [д3],[дж] & {$[\breve{и}],[ц],[ш],[ж][3],[c]$} & [ч] \\
\hline 8 & {$[б],[\mathrm{M}],[\Pi],[\mathrm{в}],[\phi]$} & [л], [н] & [дз],[дж] & {$[$ [й],[ц],[ш],[ж] [с] } & [ч], [л] \\
\hline
\end{tabular}

\section{Висновки}

У відповідності із поставленою метою дослідження можемо констатувати, що зубо-щелепні аномалії негативно позначаються на комунікації в освітньому просторі. Нами виділено порушення сприйняття інформації реципієнтом у результаті неправильної артикуляції комунікантом певних звуків української мови для толерантного середовища. Встановлено, що зубощелепні аномалії та деформації призводять до порушень у роботі артикуляційного апарату, а відтак спричиняють проблеми у спілкуванні, викликають дискомфорт, непорозуміння, конфлікти та ін.

На основі експертного опитування нами визначено, що вестибулярне положення іклів негативно впливає артикуляцією приголосних звуків української мови, чіткість вимови яких вимагає правильної будови та функціонування зубів у процесі творення струменя видихуваного повітря.

\section{Література}

1. Аюпова Ф.С. Частота различных видов зубочелюстных аномалий у детей 7-17-летнего возраста. Тезисы зональной научно-технической конференции «Актуальные вопросы ортодонтического лечения». Иркутск. 1990. С. 7-8.

2. Персин Л. С. и др. Стоматология детского возраста. Учебник. Москва: ООО «Издательская группа ГЭОТАР-Медиа», 2016. Ч. 3. Ортодонтия. С. 240-240.

3. Закон України «Про повну середню освіту». Голос України. 2020. URL: https://zakon.rada.gov.ua/laws/ show/463-20\#Text.

4. Розлуцька Г.М., Сокол М.О., Іваничко I.І. Трансформація принципу культуровідповідності у організації толерантного освітнього простору. Problems and Innovations in Science. Abstracts of the 1st International scientific and practical conference. Nika Publishing. London, Great Britain. 2020, V.2 Pp. 95-100. URL: http://elconf.com.ua.

5. Смолюк, С.В. Організаційно-педагогічні умови розвивального освітнього середовища в системі освіти України (кінець XX - початок XXI ст.) : дис. ... канд. пед. наук : 13.00.01 / Луцьк: Східноєвропейський національний університет імені Лесі Українки. 2015. 240 с.

6. Цимбалару А. Д. Освітній простір: сутність, структура і механізми створення. Український педагогічний журнал. 2016. Т. 1. С. 41-50.

7. Академічний тлумачний словник української мови (1970-1980). URL: http://sum.in.ua/s/artykuljacija.

8. Гаврилова Н.С. Анатомо-фізіологічні особливості периферійних органів мовлення. Актуальні питання корекційної освіти. 2014. URL: file:///Z:/User/Downloads/apko_2014_4_6\%20(2).pdf.

9. Дорошенко О. М. Дослідження функціонального стану жувальних м’язів у пацієнтів різних вікових груп із сагітальними аномаліями прикусу. Збірник Наукових праць співробітників НМАПО ім. П.Л. Шупика. 2015. Вип.24 (2). C. 58-62.

10. Петриченко О.В. Клінічна характеристика щелепно-лицьової ділянки ортодонтичних пацієнтів із порушеннями мовлення. Збірник Наукових праць співробітників НМАПО ім. П.Л. Шупика. 2016. Вип. 25. С. $491-496$.

11. Хинц Р. Профилактика зубочелюстных аномалий у детей в раннем возрасте / Рольф Хинц // Ортодонтия. 2011. - №2. - C. 27-29. 
12. Лихота К.М., Петриченко О.В., Цянь Чжан. Взаємозв’язок аномалій і деформацій прикусу з функціональним станом щелепно-лицевої ділянки (огляд літератури). Збірник Наукових праць співробітників НМАПО ім. П.Л. Шупика. 2018. Вип. 32. С. 231-238.

\section{References}

1. Ayupova F.S. (1990) Chastota razlichnyih vidov zubochelyustnyih anomaliy u detey 7-17-letnego vozrasta. Tezisyi zonalnoy nauchno-tehnicheskoy konferentsii «Aktualnyie voprosyi ortodonticheskogo lecheniya». Irkutsk. S. 7-8. \{The incidence of various types of dentoalveolar anomalies in children aged 7-17 years.)) \}. (In Russian).

2. Persin L. S. i dr. (2016) Stomatologiya detskogo vozrasta. Uchebnik. Moskva: OOO «Izdatelskaya gruppa GEOTAR-Media». Ch. 3. Ortodontiya. S. 240-240. \{Dentistry of children.))\}. (In Russian).

3. Zakon Ukrainy (2020) «Pro povnu seredniu osvitu». Holos Ukrainy. URL: https://zakon.rada.gov.ua/laws/ show/463-20\#Text \{Law of Ukraine)) \}. (In Ukrainian).

4. Rozlutska H.M., Sokol M.O., Ivanychko I.I. (2020) Transformatsiia pryntsypu kulturovidpovidnosti u orhanizatsii tolerantnoho osvitnoho prostoru. Problems and Innovations in Science. Abstracts of the 1st International scientific and practical conference. Nika Publishing. London, Great BritainV.2 Pp. 95-100. URL: http://elconf.com.ua/ \{Transformation of the principle of cultural acceptance in the organization of a tolerant education space.)) $\}$. (In Ukrainian).

5. Smoliuk, S.V. (2015) Orhanizatsiino-pedahohichni umovy rozvyvalnoho osvitnoho seredovyshcha v systemi osvity Ukrainy (kinets KhKh - pochatok KhKhI st.) : dys. ... kand. ped. nauk : 13.00.01 / Lutsk: Skhidnoievropeiskyi natsionalnyi universytet imeni Lesi Ukrainky. 240. \{Organizational and pedagogical thinking of the developmental educational center in the system of education of Ukraine (the beginning of the XX - the ear of the XXI century).)) \}. (In Ukrainian).

6. Tsymbalaru A. D. (2016) Osvitnii prostir: sutnist, struktura i mekhanizmy stvorennia. Ukrainskyi pedahohichnyi zhurnal. T. 1. S. 41-50. \{Educational space: concept, structure and formation mechanisms).))\}. (In Ukrainian).

7. Akademichnyi tlumachnyi slovnyk ukrainskoi movy (1970-1980). URL: http://sum.in.ua/s/artykuljacija \{Academic vocabulary of Ukrainian language (1970-1980)).))\}. (In Ukrainian).

8. Havrylova N.S. (2014) Anatomo-fiziolohichni osoblyvosti peryferiinykh orhaniv movlennia. Aktualni pytannia korektsiinoi osvity. URL: file:///Z:/User/Downloads/apko_2014_4_6\%20(2).pdf \{Anatomical and physiological features of peripheral organs of the movement.))\}. (In Ukrainian).

9. Doroshenko O. M. (2015) Doslidzhennia funktsionalnoho stanu zhuvalnykh miaziv u patsiientiv riznykh vikovykh hrup iz sahitalnymy anomaliiamy prykusu. Zbirnyk Naukovykh prats spivrobitnykiv NMAPO im. P.L. Shupyka. Vyp.24 (2). S.58-62. \{Study of the functional state of the masticatory muscles in patients of different age groups with sagittal occlusion anomalies.))\}. (In Ukrainian).

10. Petrychenko O.V. (2016) Klinichna kharakterystyka shchelepno-lytsovoi dilianky ortodontychnykh patsiientiv iz porushenniamy movlennia. Zbirnyk Naukovykh prats spivrobitnykiv NMAPO im. P.L. Shupyka. 2016. Vyp. 25. S. $491-496$. \{Clinical characteristics of the maxillofacial area of orthodontic patients with speech disorders.)) \}. (In Ukrainian).

11. Hints R. (2011) Profilaktika zubochelyustnyih anomaliy u detey v rannem vozraste / Rolf Hints // Ortodontiya. №2. S. 27-29. \{Prevention of dental anomalies in children at an early age.)) \}. (In Russian).

12. Lykhota K.M., Petrychenko O.V., Tsian Chzhan. (2018) Vzaiemozviazok anomalii i deformatsii prykusu z funktsionalnym stanom shchelepno-lytsevoi dilianky (ohliad literatury). Zbirnyk Naukovykh prats spivrobitnykiv NMAPO im. P.L. Shupyka. Vyp. 32. S. 231-238. \{Relationship between occlusal anomalies and deformities and the functional state of the maxillofacial area (literature review) \}. (In Ukrainian).

Дата надходження рукопису до редакції: 14.07.2020 p.

Мета - виявити вплив зубо-щелепних аномалій на комунікацію в освітньому просторі.

Завдання: визначити особливості комунікації у просторі освіти; окреслити вплив правильної вимови на толерантну взаємодію учасників освітнього середовища; розглянути роль зубних рядів як органів артикуляційного апарату у вимові звуків; на основі експертного опитування визначити вплив між артикуляцією звуків української мови та вестибулярним положенням іклів.

Матеріали та методи. Міждисциплінарні наукові підходи зумовили використання дослідницького інструментарію різних галузей, а саме: мовознавства, психології, соціології, культурології, логопедії, ортодонтії. Застосовано емпіричні, аналітико-синтетичні методи дослідження при аналізі джерел і науково-методичної літератури. Системний підхід до об'єкта дослідження спонукав до структурно-функціонального аналізу, інтерпретації та узагальнення результатів.

Висновки. Дослідженням доведено, що зубо-щелепні аномалії негативно позначаються на комунікації в толерантному освітньому просторі. Вказано, що зубо-щелепні аномалії та деформації призводять до порушень у роботі артикуляційного апарату, а відтак спричиняють проблеми у спілкуванні, викликають дискомфорт, непорозуміння, конфлікти та ін. На основі експертного опитування визначено, що вестибулярне положення іклів негативно впливає артикуляцією приголосних звуків української мови. 
Перспективи подальших досліджень. Наше дослідження не вичерпує усіх аспектів окресленої проблеми. Перспективним напрямом подальшої роботи вважаємо розробку методичних рекомендацій для практичної діяльності логопедів та ортодонтів по усуненню дефектів мовлення.

Практичне значення роботи у акцентуванні уваги на спільній діяльності логопедів та ортодонтів по усуненню мовних дефектів пов'язаних із аномаліями та деформаціями зубі.

Наукова оригінальність роботи полягає у визначенні груп звуків української мови, які не правильно артикулюються при умові вестибулярного положення іклів.

Ключові слова: порушення комунікації, толерантне середовище, артикуляція, зубо-щелепні аномалії, вестибулярне положення іклів.

Цель - выявить влияние зубо-челюстных аномалий на коммуникацию в образовательном пространстве.

Задачи исследования: определить особенности коммуникации в пространстве образования; определить влияние правильного произношения на толерантную взаимодействие участников образовательной среды; рассмотреть роль зубных рядов как органов артикуляционного аппарата в произношении звуков; на основе экспертного опроса определить влияние между артикуляцией звуков украинского языка и вестибулярным положением клыков.

Материалы и методы. Междисциплинарные научные подходы обусловили использование исследовательского инструментария различных отраслей, а именно: языкознания, психологии, социологии, культурологии, логопедии, ортодонтии. Применен эмпирические, аналитико-синтетические методы исследования при анализе источников и научно-методической литературы. Системный подход к объекту исследования вызвал структурно-функционального анализа, интерпретации и обобщения результатов.

Выводы. Исследованием доказано, что зубо-челюстные аномалии негативно сказываются на коммуникации в толерантном образовательном пространстве. Указано, что зубо-челюстные аномалии и деформации приводят к нарушениям в работе артикуляционного аппарата, а затем вызывают проблемы в общении, вызывают дискомфорт, недоразумения, конфликты и др. На основе экспертного опроса определено, что вестибулярное положение клыков негативно влияет артикуляцией согласных звуков украинского языка.

Перспективы дальнейших исследований. Наше исследование не исчерпывает всех аспектов обозначенной проблемы. Перспективным направлением дальнейшей работы считаем разработку методических рекомендаций для практической деятельности логопедов и ортодонтов по устранению дефектов речи.

Практическое значение работы в акцентировании внимания на совместной деятельности логопедов и ортодонтов по устранению речевых дефектов связанных с аномалиями и деформациями зубе.

Научная оригинальность работы заключается в определении групп звуков украинского языка, не правильно артикулируются при условии вестибулярного положения клыков.

Ключевые слова: нарушение коммуникации, толерантное среду, артикуляция, зубо-челюстные аномалии, вестибулярное положение клыков.

The aim of the study is to identify the impact of dental anomalies on communication in the educational space.

Tasks of the study: to determine the features of communication in the space of education; outline the impact of correct pronunciation on the tolerant interaction of participants in the educational environment; consider the role of dentitions as organs of the articulatory apparatus in the pronunciation of sounds; on the basis of an expert survey to determine the influence between the articulation of the sounds of the Ukrainian language and the vestibular position of the canines.

Materials and methods. Interdisciplinary scientific approaches have been led to the use of research tools in various fields, namely: linguistics, psychology, sociology, culturology, speech therapy, orthodontics. Interdisciplinary scientific approaches have led to the use of research tools in various fields, such as: linguistics, psychology, sociology, culturology, speech therapy, orthodontics. Empirical, analytical-synthetic research methods have been used in the analysis of sources and scientificmethodical literature. A systematic approach to the object of study has been encouraged to structural and functional analysis, interpretation and generalization of results.

Conclussions. The research has shown that dental anomalies negatively affect communication in a tolerant educational space. It has been stated that dental anomalies and deformations lead to disorders of the articulatory apparatus, and thus cause problems in communication, cause discomfort, misunderstandings, conflicts and others. Based on an expert survey, it has been determined that the vestibular position of the canines has a negative effect on the articulation of consonant sounds of the Ukrainian language.

Prospects for further research. Given study does not cover all aspects of the outlined problem. It has been considered that the development of methodological recommendations for the practical activities of speech therapists and orthodontists to eliminate speech defects is a promising area of further work.

The practical significance of the work is to focus on the common activities of speech therapists and orthodontists to eliminate speech defects associated with abnormalities and deformities of the tooth.

The scientific originality of the work lies in the definition of groups of sounds of the Ukrainian language, which are not correctly articulated under the condition of the vestibular position of the canines. 
Key words: communication disorders, tolerant environment, articulation, dental-maxillary anomalies, vestibular position of canines.

Конфлікт інтересів: відсутній.

Conflicts of interest: authors have no conflicts of interest to declare.

\section{Відомості про авторів}

Розлуцька Галина Миколаївна - доктор педагогічних наук, доцент, професор кафедри загальної педагогіки та педагогіки вищої школи ДВНЗ «Ужгородський національний університет»; м. Ужгород, Україна.

+380 (50) 909-31-13, grozlutska@ukr.net.

Іваськевич Вікторія Зіновіївна - викладач кафедри стоматології дитячого віку ДВНЗ «Ужгородський національний університет»; м. Ужгород, Україна.

+380 (66) 267-54-45, vikiblonda@gmail.com. 